\title{
ENABLING EVENT VOLUNTEER LEGACIES: A KNOWLEDGE MANAGEMENT PERSPECTIVE
}

\author{
DEBORAH BLACKMAN,* ANGELA M. BENSON,† AND TRACEY J. DICKSON $\ddagger$ \\ *School of Business, UNSW, Canberra, Australia \\ †School of Sport and Service Management, University of Brighton, Eastbourne, UK \\ $\ddagger$ Faculty of Business, Government and Law, University of Canberra, Bruce, Australia
}

\begin{abstract}
Human capital development delivered through the volunteers is espoused as one legacy outcome of hosting mega-sporting events such as the Olympic and Paralympic Games. However, to date the reality of such a legacy remains largely undemonstrated. In this article, Nonaka and Tacheuchi's SECI model and Lee and Yang's knowledge value chain (KVC) are integrated to identify insights to support the development of a potential human capital legacy from volunteers in future mega-sport events through focusing on knowledge management. A case study of the Vancouver 2010 Olympic and Paralympic Winter Games demonstrates gaps in the knowledge management systems in place, both in terms of the identification of knowledge and the processes for capture and reuse. It is argued that, unless those involved in hosting the events reconsider their approach to human capital legacy development, using the creation and management of knowledge as a core element, it is unlikely that long-term human capital legacy outcomes will be achieved for host communities.
\end{abstract}

Key words: Knowledge legacy; Human capital; Strategic knowledge management; Knowledge value chain (KVC); Volunteers

\section{Introduction}

When bidding to host mega-sporting events, such as the Olympic and Paralympic Games, one of the arguments made by both bid selectors and the host community is the benefit to be gained from the legacy that will be left behind (e.g., Azzoni, 2009; Gold \& Gold, 2008; Hiller, 2000; Sochi, 2009, 2014; VANOC, 2010), with legacy being seen as something remaining for the host community (Dickson, Benson, \& Blackman, 2011; Preuss, 2007; Williams \& Elkhashab, 2012). Research has typically focused on the tangible legacies of the economy, infrastructure, and urban renewal, "measured" either prior to the event or immediately after the event, (e.g., Andranovich, Burbank, \& Heying, 2001; Kasimati, 2003; Kissoudi, 2008), with little focus on other areas such as social legacies, human 
capital development (Benson, Dickson, Terwiel, \& Blackman, 2014), growth in sports participation (Cashman, 2006; Chalip, 2006; Dickson et al., 2011), or knowledge management that may benefit future event organizing committees (Halbwirth \& Toohey, 2001). This research gap is surprising considering (a) the number of volunteer positions involved (e.g., 25,000 in the Vancouver 2010 Games ${ }^{1}$ and 70,000 at the London 2012 Games $^{2}$ ), and (b) the scale of the public and private investment to host these events ("Olympics cost B.C. \$925M,” 2010; Taylor, 2013; VANOC, 2010). There is a considerable, and growing, body of research into volunteer motivations, retention, and/or legacy in a range of sport-related contexts (e.g., Dickson, Benson, Blackman, \& Terwiel, 2013; Doherty, 2009; Hallmann, \& Harms, 2012; Love, Hardin, Koo, \& Morse, 2011; Peachey, Lyras, Cohen, Bruening \& Cunningham, 2013) and some emerging work in the area of knowledge management across the events themselves (Parent, MacDonald, \& Goulet, 2014). However, there is little understanding of how the experience, knowledge, and/or skills gained by volunteers during an event is acquired, exploited, or applied in other contexts, nor how that knowledge may be managed better for the benefit of others in the future. This inhibits the potential human capital, or volunteer, legacy for the host community beyond the event.

The importance of knowledge is that it enables an individual to recognize new ideas, make distinctions, and exercise judgment reflecting the context, thereby making appropriate decisions (Davenport \& Prusak, 2000; Tsoukas \& Vladirimou, 2001). Knowledge management (KM) is where knowledgerelated activities are explicitly managed through a range of practices, policies, and programs in order to systematically provide ways to capture and utilize it (C. C. Lee \& Yang, 2000). This desire for knowledge capture and reutilization is often cited in event bids [e.g., Department of Culture, Media and Sport Committee (DCMS), 2003; Sochi, 2009, 2014; VANOC, 2010] and is therefore considered one form of a potential mega-event legacy. To explore the nexus between mega-sport events and knowledge management, this article will firstly outline why, theoretically, the development of human capital from volunteers, in this case in a sport-event context, is a legacy that should be considered as a
KM strategy. Second, the SECI model (Nonaka \& Tacheuchi, 1995) is used to explain how knowledge is created and why this needs particular consideration when managing volunteers. Third, the knowledge value chain (KVC) (C. C. Lee \& Yang, 2000) is provided as an example of a $\mathrm{KM}$ model, which could facilitate the development of such a legacy. We stress there is no perfect model but that it is the thinking triggered by the model adoption and, thus, the management of new knowledge related to volunteers, that matters. Fourth, a case study of the Vancouver 2010 Games is analyzed demonstrating gaps in the KM approach undertaken and outlining some of the potential implications of this. The article concludes that the practices used for volunteering in Vancouver 2010 Games were not acting as an effective KM system, thus limiting the legacy potential and offers lessons learned for future host cities and volunteer organizations.

\section{Human Capital Legacy as a Knowledge Outcome}

The term human capital has been used in the human resources management and development literatures for some time comprising both 1) the skills, abilities, and knowledge held by individuals (their intellectual capital), and 2) their ability to utilize these attributes, for the achievement of a particular goal (Coleman, 1988; Crook, Todd, Combs, Woehr, \& Ketchen, 2011; Gratton \& Ghoshal, 2003). The importance of human capital has been acknowledged in the volunteering literature (Forbes \& Zampelli, 2014; Wilson, 2000; Wilson \& Musick, 1998), but it is usually used as an indicator of the likelihood to volunteer as predicted by the level of education. The idea of how human capital should be actively managed through $\mathrm{KM}$ is not currently addressed in the event and volunteer literature. As previously noted, for mega-sport event volunteers it appears that the organizers hope and expect that volunteers will develop new knowledge or skills, then transfer and reuse them in other tourism, hospitality, or event contexts (Benson et al., 2014; DCMS, 2010; Sochi 2009, 2014; VANOC, 2010). It is this hope to plan, capture, and, potentially, reuse knowledge through volunteers in other contexts that makes the potential for a human capital legacy a KM matter (Dalkir, 2011; Hsu \& Sabherwal, 2012; Seleim \& Khalil, 2011). 
The importance of knowledge as a source of added value or competitive advantage is widely accepted in the organization/management literature (e.g., Eisenhardt, \& Santos, 2002; Grant, 1996; Nickerson, \& Zenger, 2004), and has more recently become of some interest in the event and tourism literature (e.g., Cooper, 2006; Halbwirth \& Toohey, 2001; Shaw \& Williams, 2009; Stadler, Fullagar, \& Reid, 2014; Yang \& Wan, 2004), as well as the volunteering literature more generally (e.g., Lettieri, Borga, \& Savoldelli, 2004; Liu \& Ko, 2012). Articles published to date predominantly focus on the need for $\mathrm{KM}$ and an associated research agenda rather than offering suggestions on how to actually capture and/or use knowledge effectively. We suggest that the paucity of research in these fields that are dependent on people, particularly volunteers, is a lost opportunity to leverage the existing knowledge and skills of volunteers that has been value added by their mega-event training and experiences (Benson et al., 2014) for the benefit of the broader volunteering community. This research gap is what we seek to address.

The various KM models and implementation strategies discussed in the literature (see e.g., Dalkir, 2011; Heisig, 2009; Hislop, 2013; Newell, Robertson, Scarborough, \& Swan, 2009, K. Y. Wong \& Aspinall, 2004) outline different process and infrastructure requirements necessary to enable the three types of knowledge to be developed and utilized effectively. Their differences focus on the way that they conceptualize knowledge creation, storage, and reuse. In this article, we use two structural models, the SECI model (Nonaka \& Tacheuchi, 1995) and the knowledge value chain (KVC) (C. C. Lee \& Yang, 2000), in order to offer insights into human capital legacy development.

A structural model of knowledge assumes that knowledge creation requires the identification of tacit knowledge, which can be made explicit and then converted back into a tacit form to be used elsewhere (Newell et al., 2009). Tacit knowledge is personal knowledge comprising of a range of conceptual and sensory information and images that an individual uses to make sense of something (Ambrosini \& Bowman, 2001; Hodgkin 1992). It is unwritten, unspoken, and internalized and is therefore hard to explain to others, being based on individual experiences, observations, and emotions leading to what can be seen as intuitive understandings. In terms of the Games ${ }^{3}$, volunteers will bring tacit knowledge based on their previous experiences in the workplace, helping at previous events or from other volunteering contexts. This will affect how they understand what is asked of them and how they approach the task. For some volunteers their tacit knowledge will be about their expectations of the Games themselves and what their role will be; if they find there is a mismatch there may be low levels of satisfaction that may impact their intention to volunteer in the future (Dickson, Darcy, Edwards, \& Terwiel, 2015).

Conversely, explicit knowledge may be articulated, codified, stored, and transferred easily to others. The Organizing Committees for the Olympic Games ${ }^{4}$ (OCOG) are all given handbooks on every aspect of the Games, outlining everything they need to know based on prior Games experience to enable running successful Games, which is a clear example of explicit knowledge. Additionally, debriefing sessions are held after the event, entitled transfer of knowledge, to facilitate the transfer of knowledge from one OCOG to the next. When one looks at the handover from Torino 2006 to Vancouver 2010, the focus on human legacy considered just two questions, covered in two PowerPoint slides: volunteer motivations and interest in volunteering in the future [International Olympic Committee (IOC), 2006].

Although there is critique of both the assumptions underpinning structural models of knowledge and the models themselves in terms of whether knowledge is something that can be captured and whether tacit knowledge can really be recognized or made explicit (see e.g., Cook \& Brown, 1999, Gherardi, 2006; Hislop, 2013), there is widespread use and adoption of them as useful frameworks for considering how to improve knowledge creation, use, and transfer in organizations.

\section{The SECI Model}

According to Nonaka and Takeuchi (1995; see also Cook \& Brown, 1999; Nonaka, 1994), knowledge is created through continuous, dynamic interaction between tacit and explicit knowledge, what they refer to as the "knowledge creation spiral" that leads to four different forms of conversion 
within the SECI model as discussed below. The underpinning premise of the SECI model is that for knowledge to be useful it must be articulated by individuals and transferred to others who can then internalize and use it in some way. It is the process of restructuring existing knowledge that enables it to be exploited. Despite considerable criticism of the model, which argues that it is too individualistic and not empirically sound (see e.g., Gourlay, 2006; Harmaakorpi \& Melkas, 2005), its usefulness is reflected in its application across a range of disciplines and contexts including accounting (Cai, 2014), cross-cultural studies (Easa \& Fincham, 2012), librarianship (C. S. Lee \& Kelkar, 2013), organizational learning (Hong, 2012), and engineering (Sarirete \& Chikh, 2010). It has been chosen for this study as its structural focus fits with the KVC approach, while supporting the ideas of the need to move ideas from one place to another to create knowledge, which can then be captured (see also Cook \& Brown, 1999).

Following, the four forms of conversion that give rise to the SECI model's names are discussed and examples provided from a mega-event context.

Socialization is the first form of conversion and relates to the sharing of tacit knowledge to tacit knowledge through face-to-face communication or shared experience, informal social intercourse, and teaching by practical examples. An example in terms of legacy could be new volunteers working with previous volunteers to learn how to best manage an element of an event using techniques or ideas not in a formal handbook or briefing. This might be seen when showing new volunteers how to move around alpine race courses in an effective way, or when members of future megaevent OCOGs participate in the IOC Observer Program to watch how things are done (Sochi, 2009, 2014).

Externalization is the process of converting tacit knowledge to explicit knowledge by developing concepts and models. In this phase, tacit knowledge is converted to an understandable and interpretable form, so others can also use it. The OCOG knowledge transfer handbooks (see e.g., IOC, 2006) could be seen as an example of this. Those who have long-term experience of the Games reflect on the latest Olympic event and then develop new protocols, etc., from the lessons learned.
Combination is the process that addresses the integration of different forms of explicit knowledge, compiling externalized explicit knowledge and sharing it to other entities or integrating it into different systems. In this phase, knowledge is also analyzed and organized in order to decide what to combine. The use of the KM files prepared by an OCOG at the end of each Games enables the successive OCOG to reflect on a range of learning and develop new strategies based on the learning of each of their predecessors. Moreover, the knowledge transfer process, where the formal reports are presented and more in-depth informal discussion undertaken enables the new team to clarify issues and create new understandings.

Internalization means understanding explicit knowledge. It happens when explicit knowledge transforms to tacit and becomes a part of individual's basic information. This is where everyone recognizes something and acts on it. It is, in theory, what happens at the volunteers' orientation to provide shared understandings of the tasks to be done, the way they will be done, and what the processes will be to ensure the smooth running of the games. As volunteers often work unsupervised, transferring knowledge effectively is critical to the smooth running of the event. At the Vancouver 2010 Games volunteers were given radios and a core part of the orientation were the communication skills needed to be use them well- these included listening and being respectful to others.

Each of these four conversions possesses distinctive practices and the interplay between them constitutes a dynamic process of knowledge creation that will enable increased capacity. KM becomes the active planning of ways to trigger and support the spiral (see Fig. 1) and then capturing the emergent explicit knowledge for it to then be used again. We propose that one way to operationalize this for mega-event organizers is to employ the KVC model. The two models have been linked together before showing how SECI is the process and KVC offers a structure to support the implementation (see e.g., Lin \& Tseng, 2005; H. K. Wong, 2004).

\section{The KVC Model}

The KVC model has been less widely adopted than the SECI model; however, it incorporates many 


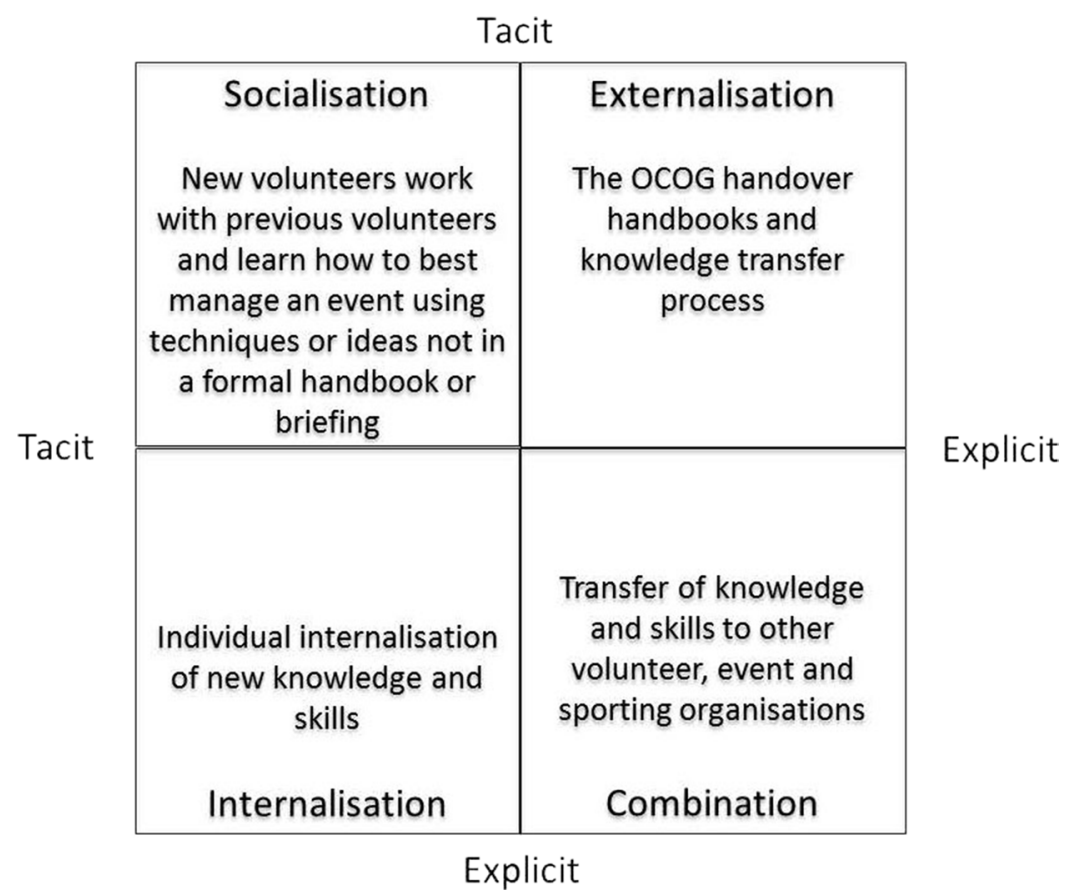

Figure 1. The SECI model. Source: Nonaka and Takeuchi (1995).

of the elements used when analyzing a KM system such as structure, people, and processes that may provide direction for organizations to implement change (Ghaffar, Beydoun, Shen, \& Tibben, 2011). A value chain is a sequence of activities undertaken by an entity (usually an organization) that enables the development of something that will be of benefit to at least one of its stakeholders; these are usually the customers of a private company or the public in the case of government. Originally designed for the enhancement of products being developed for sale, Porter (1985) argued that for products to be worth more than the sum of the worth of the independent activities, products must pass through all activities of the chain. C. C. Lee and Yang (2000), arguing that the role of knowledge was to permit the adding of value in an organization, adapted the value chain model to a knowledge context. They argued that knowledge should move through the complete chain to gain maximum value (Fig. 2); although benefit could be gained in adopting some parts of the chain if not all parts were available (for example there might not be a knowledge officer).

The KVC has two major sections: infrastructure and processes. The infrastructure is made up the elements of the organization, which enable an organization to create a product, or service, which is seen to provide or add value. The infrastructure will be designed to support the processes, which actually enable the identification, creation, capture, and utilization of knowledge. When linked with the SECI model the processes will enable the creation and continuation of the spirals.

Historically, the KM literature has either focused on infrastructure, such as information technology that supported the initiatives, rather than the people and processes (e.g., Chalkiti \& Sigala, 2008; Cooper, 2006), or on creation of knowledge through social interactions and movement of people (Chua, 2002; Nonaka \& Toyama, 2003). The integration of both infrastructure and processes is the advantage of the KVC approach, reflecting both the need to have formal systems to capture, store, and then access knowledge for later use, as well as recognizing the role of individuals in knowledge creation, capture, integration, and application. There is an argument that the KVC is too linear in its approach (Powell, 2001; Swan, Newell, Scarborough, \& Hislop, 1999) and that seeing the knowledge as moving through the chain does not reflect its complex nature, nor 


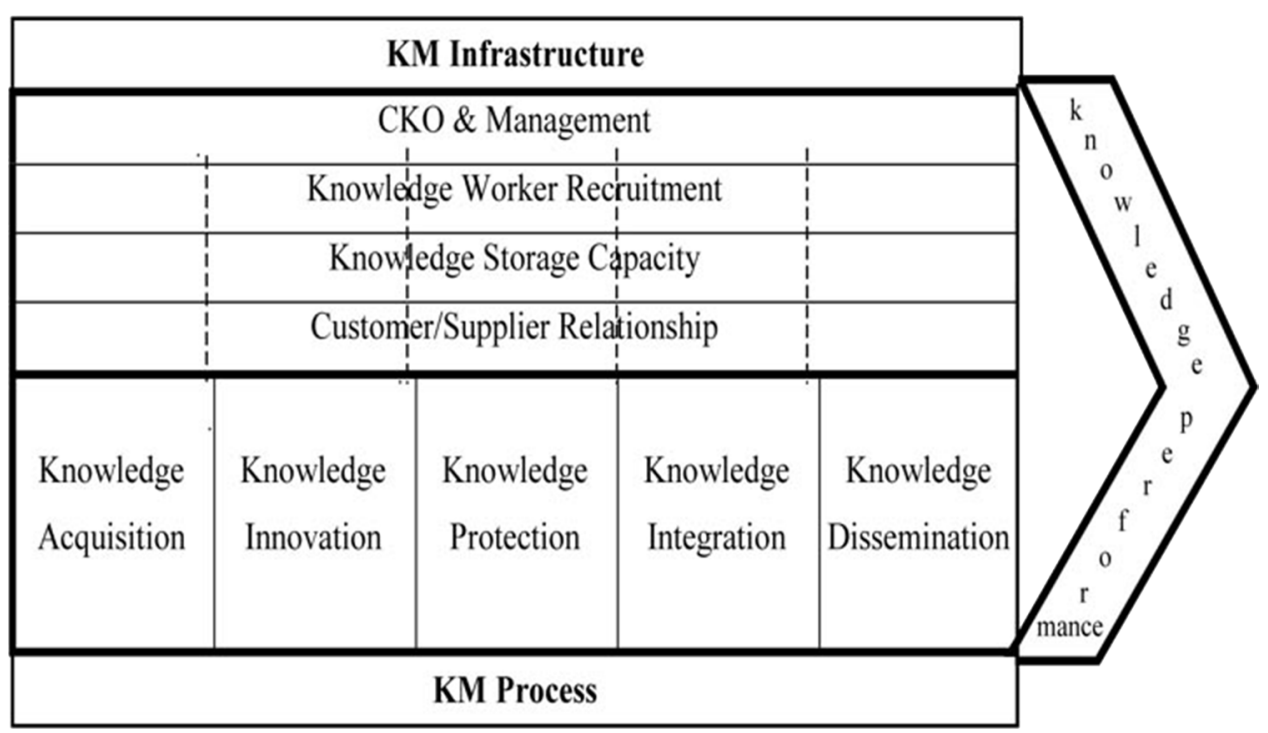

Figure 2. Knowledge value chain. Source: C. C. Lee and Yang (2000).

the difficulty in using it for future advantage. For this reason, we advocate the integration of the SECI model with the KVC. Instead of just being a sequence of potentially value-adding activities, the KVC can be conceptualized as a way to develop the SECI spirals required to create knowledge and as a way to formally consider how to capture all forms of knowledge.

\section{Methodology}

When undertaking this research two contributions to the KM/legacy debate were planned: firstly, to identify how both volunteers, and organizations that use volunteers, were expected to enable legacy, and, secondly, to establish how likely it was that such knowledge transfer occurred. There was no intention to generalize from the case, rather the aim was to establish what took place, or could have taken place, in relation to one event and consider what learning could be developed from there. A case-study approach was chosen in order to achieve this.

The case being analyzed is the Vancouver 2010 Games; however, despite being called the Vancouver 2010 Games, venues for these Games were shared between Vancouver and Whistler (an alpine resort about an hour from Vancouver). This case was chosen because of the organizing committee's (VANOC) focus on creating community legacies and the high expectation that the volunteers would form the basis for a pool of skilled volunteers for future events and volunteering in other contexts (e.g., Rae, 2008; VANOC, 2010).

The central theme of bidding for and hosting the 2010 Winter Games is to create sustainable legacies. . . . VANOC's goal is to leave legaciesphysical and human - that will last long after the final medal of the Games is awarded. (VANOC, 2008, in Dickson, Terwiel, \& Benson, 2011, p. 222)

The Vancouver 2010 Games' legacy for the community is further articulated as:

The Games will create a legacy around the development of skills. The Games provide valuable opportunities to enhance the region's hospitality and event hosting expertise along with training and the development of new skills for the Four Host First Nations (FHFN), Aboriginal people and inner-city communities as they participate in delivering the Games services. (VANOC, 2008, in Dickson, Terwiel et al., 2011, p. 223)

VANOC was a not-for-profit company established after the IOC awarded the Games to Vancouver and Whistler in 2003. VANOC's mandate was to plan, finance, and stage the Vancouver 2010 Games, 
which were expected to require 25,000 volunteers in addition to the 30,000 paid and temporary staff, contractors, and ceremony participants (VANOC, 2010). Volunteers could be allocated to any one of the 30 functional or job areas (VANOC, 2010) that included antidoping, food and beverage, medical services, sport events, transportation, and workforce.

The case study approach is appropriate as it enables an in-depth investigation into a specific set of circumstances in a particular context, and is particularly relevant where the observer has access to a novel, previously unexplained phenomenon (Yin, 2014). This case study was constructed from data gathered before, during, and after the Games, through (a) in-depth interviews, (b) a reflective workshop, (c) document analysis, and (d) reflection on the quantitative analysis about training and development at the Games already analyzed and in the public domain ${ }^{5}$ (Benson et al., 2014; Dickson et al., 2013; Dickson, Terweil et al., 2011).

Interviewees were initially recruited because of referrals from the International Paralympic Committee (IPC) approval process, this then developed into a snowball sample through networks and referrals from previously interviewed respondents. In qualitative research the numbers usually prevent either informational redundancy or theoretical saturation (Sandelowski, 1995); instead the use of purposive (Sandelowski, 1995) and snowball samples (Noy, 2008) provided access to specific sets of ideas and perceptions that enabled researchers to obtain a clearer understanding of how knowledge was being developed, transferred, and captured during the Games. Twenty-three semistructured in-depth interviews were undertaken with 18 key stakeholders at three times around the Games: (1) preGames: October 2009; (2) during the Games: February/March 2010; and (3) and post-Games: September 2010 (Table 1).

Interviews ranged from $20 \mathrm{~min}$ to $1 \mathrm{hr} 40 \mathrm{~min}$. The recorded data were analyzed inductively to clarify: differences between the stakeholders and how they conceived of knowledge, the way that training occurred, whether the training was likely to lead to knowledge that would provide a legacy, which aspects of the KVC were or were not present, and how the knowledge was (or not) being stored and accessed later. Ideally, the design would have included interviewing all the key personnel at different stages of the process, however, the way the event was managed made this extremely difficult; in particular, the demobilizing of volunteers

Table 1

Stakeholders Interviewed

\begin{tabular}{|c|c|c|c|}
\hline & $\begin{array}{l}\text { Pre-Games } \\
\text { October } 2009\end{array}$ & $\begin{array}{l}\text { In-Games February/ } \\
\text { March } 2010\end{array}$ & $\begin{array}{l}\text { Post-Games } \\
\text { September } 2010\end{array}$ \\
\hline Vancouver: 2010 Legacies Now: Manager & & $\checkmark$ & $\checkmark$ \\
\hline $\begin{array}{l}\text { Vancouver: } 2010 \text { Legacies Now: Assistant responsible for post-Games } \\
\text { volunteer database }\end{array}$ & & $\checkmark$ & \\
\hline International Paralympic Committee CEO & & $\checkmark$ & \\
\hline International Paralympic Committee knowledge manager & & $\checkmark$ & \\
\hline VANOC: CEO & & & $\checkmark$ \\
\hline VANOC: Volunteer luge event official and volunteer mascot & $\checkmark$ & $\checkmark$ & \\
\hline VANOC: Volunteer coordinator & $\checkmark$ & & \\
\hline VANOC: Volunteer trainer & $\checkmark$ & & \\
\hline Resort Municipality of Whistler: Lawyer and VANOC volunteer mascot & $\checkmark$ & & \\
\hline Resort Municipality of Whistler, manager community planning & $\checkmark$ & & \\
\hline Resort Municipality of Whistler, manager strategic alliances & $\checkmark$ & & \\
\hline Tourism Whistler: Research manager & $\checkmark$ & & \\
\hline Whistler adaptive sports: Director & $\checkmark$ & $\checkmark$ & \\
\hline Whistler volunteer: Program organizer & $\checkmark$ & & \\
\hline Whistler village host: Volunteer coordinator & $\checkmark$ & & \\
\hline \multicolumn{4}{|l|}{ Other VANOC volunteers: } \\
\hline Long-term Alpine Sport event volunteers & $\checkmark \checkmark \checkmark$ & & \\
\hline Load zone attendant & & $\checkmark$ & \\
\hline National Olympic Committee assistant & & $\checkmark$ & \\
\hline Total interviews & 13 & 8 & 2 \\
\hline
\end{tabular}


at the Games' end and most of VANOC within months, made postevent interviewing impracticable, if not impossible.

A reflective workshop around the theme of legacy was undertaken 6 months after the Games at the "Volunteer BC 2010" Conference (September 24, 2010, Richmond, Vancouver) where representatives from approximately 30 organizations attended. Members of Volunteer BC reflect the broad array of organizations that benefit from volunteers, such as the MS Society, Volunteer Centers, Volunteer Information Services, and not-for-profit groups providing community care. The participants (not the same as the interview population) formed seven groups and were asked to consider five questions around issues in human capital legacy development (Table 2). Knowledge was not overtly mentioned in the questions, but the concept was raised in a preworkshop presentation that introduced the participants to the overall research project (Dickson et al., 2013). Key points from each group were manually recorded by a scribe from the feedback sessions during the workshop and typed up at a later stage. This data were then analyzed (a) for themes emerging across the different participants in terms of the development of potential human capital legacy and knowledge transfer, and (b) against the KVC model to see if the knowledge could be mapped to the stages and, if so, what were the implications of this.

In addition to these two sets of primary data, two forms of secondary analysis was undertaken: documentary and statistical. Qualitative data and findings are highly context and case dependent (Patton, 1999) and understanding the context of the case is critical to keep the data relevant to the investigation being undertaken. In this case analysis of documents used by VANOC during the Games preparation, occurrence and subsequent to, provided context (Bowen, 2009) for the case in terms of the intended legacy outcomes, espoused plans, and ideas for developing legacy and comparison with the events as thy actually unfolded. The documents included: the official International Olympic Committee Debriefing document from Torino to Vancouver, Presentations to Vancouver by the Torino Organizing Committee (IOC, 2006), which stressed educational legacy, but did not demonstrate a real human capital perspective or achievement, and Living the Dream - a post-Games report by the host community of Whistler [Resort Municipality of Whistler (RMOW), 2010]. The statistical data were drawn from previously published material in order to give context to the analysis. All data were brought together to be compared, combined, and then integrated into the case for analysis. Two lenses were used to interrogate the data. First, the KVC model was used to establish what was, and was not present, within the data. Second, the researchers reflected on the data in terms of the elements of the SECI model to provide understandings of the presence of the spiral and whether knowledge is being created, shared, and managed, and how elements of the KVC model were supporting such movements or not. All this together was used to reflect on the potential use of the KVC to trigger SECI and increase legacy potential for mega-events.

\section{Analysis Against Types of Knowledge and the Knowledge Value Chain}

The KVC is used to identify if elements were present and the typology to determine their type, thereby demonstrating any gaps in infrastructure or process elements and types, potentially explaining a lack of a coherent legacy. For the processes to be effective there must be appropriate underpinning infrastructure in place, as considered in Table 3.

Table 3 demonstrates that there was very limited KM infrastructure observed at the Games. The

Table 2

Volunteer BC 2010 Conference Workshop Questions

1. What volunteer legacy did you expect from the Games? If none, how has your understanding of legacy changed?
2. What plans did you put in place prior to the Games to facilitate that legacy?
3. What strategies are you currently still using?
4. What legacy are you seeing in your organization?
5. What can you do as an organization, when you go home, to build on or leverage the legacy from the Games? 


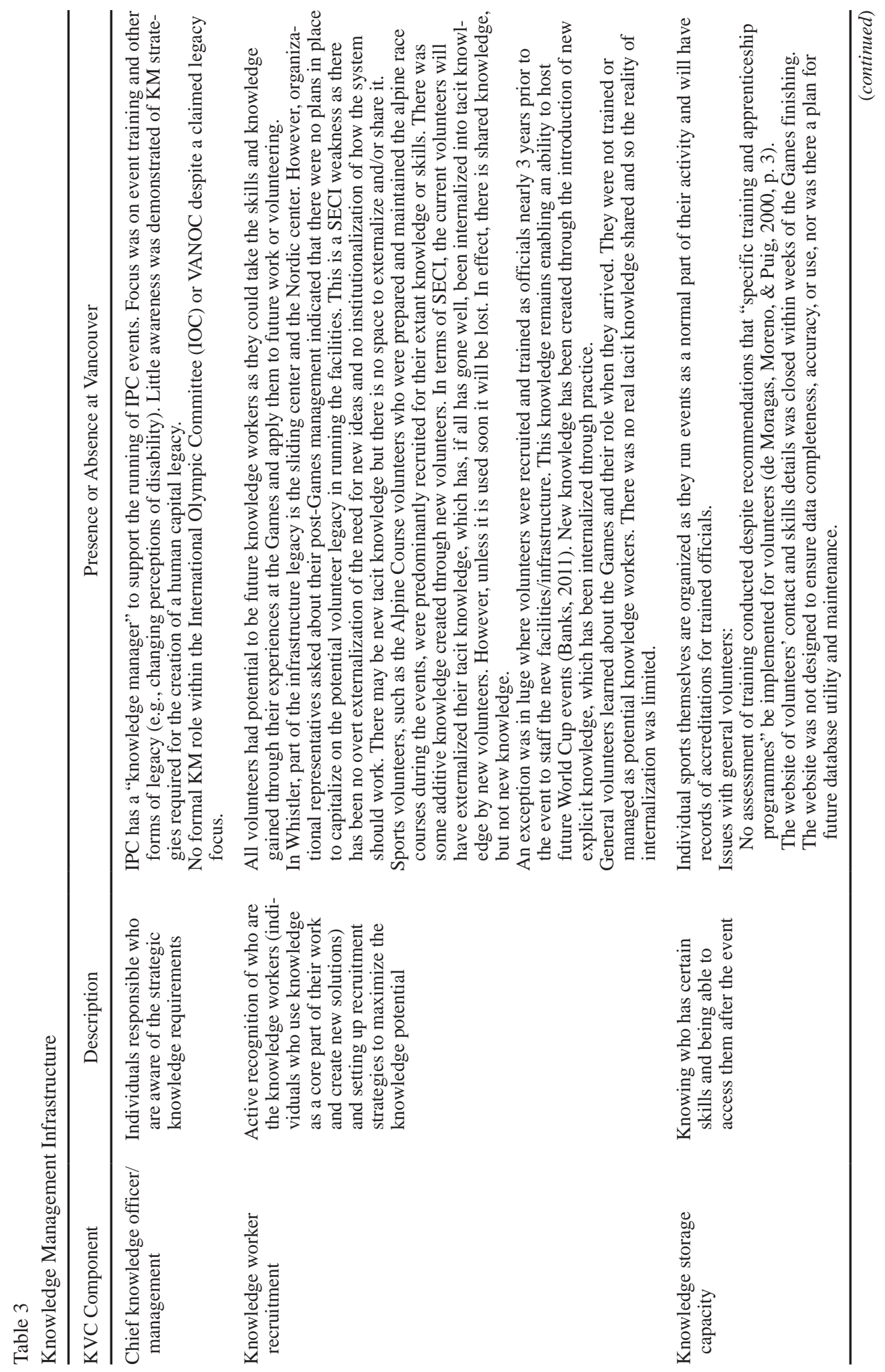




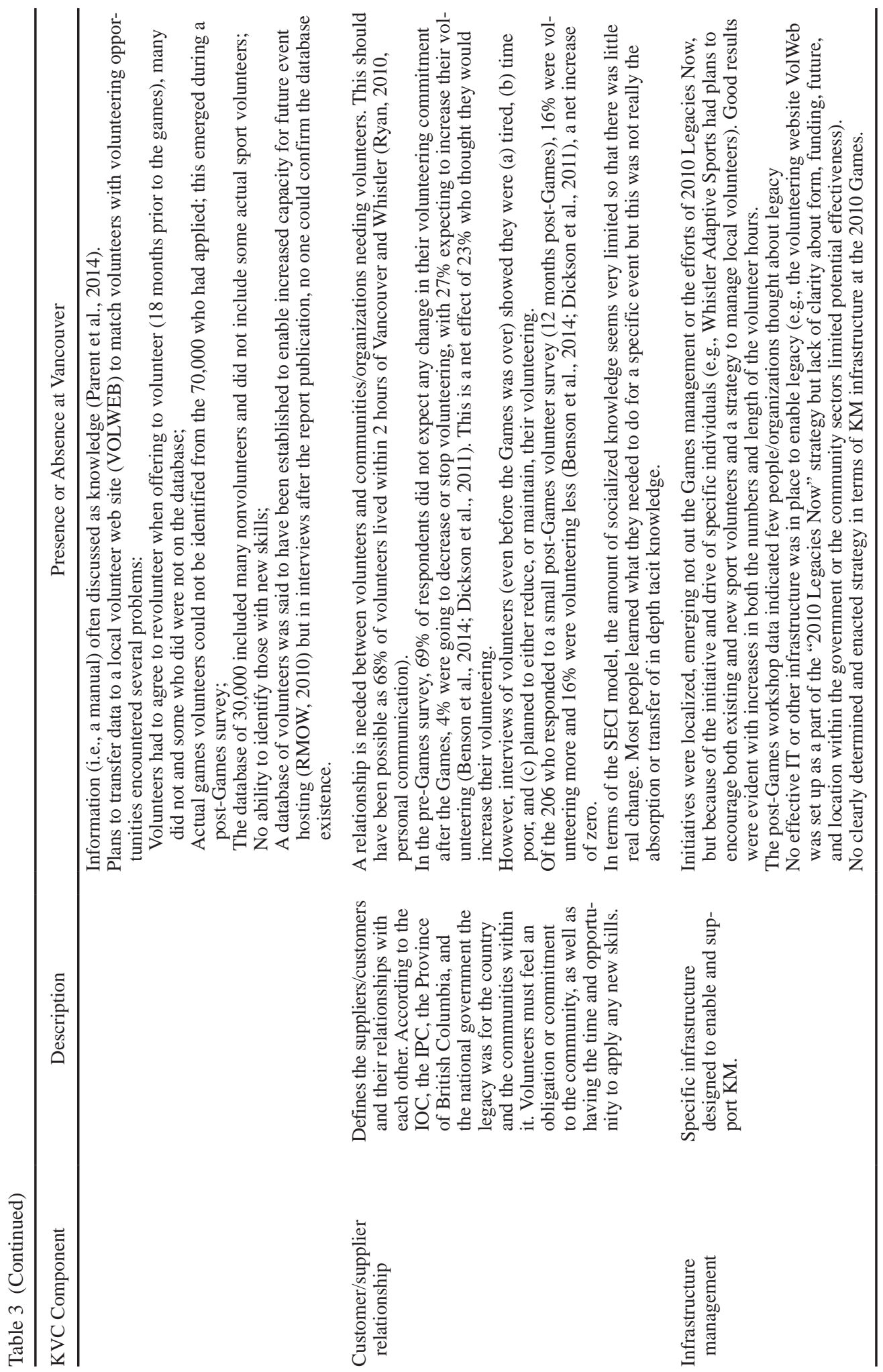


concern is that a lack of adequate systems to effectively recognize and capture knowledge prior to, during, and after the event, restricted the possibility of knowledge acquisition of any type. A clear example of this related to knowledge storage capacity was a proposal described by interviewees to develop a database of volunteers and their skills for use after the Vancouver 2010 Games, which would increase accessible capacity. However, analyzing the interviews with both those involved with setting up the database and those potentially using it later, revealed several problems: the data had been gathered at the outset of the Vancouver 2010 Games, when people first applied and did not reflect any new skills to be developed during the games; volunteers had to nominate to revolunteer 18 months prior to the games; the data base proved to be very inaccurate; and most problematic of all, actual Games volunteers could not be identified from the 70,000 who had applied. A KM approach would have stressed the need to know what knowledge was where at the end of the Vancouver 2010 Games in order to have access to capacity. Consequently, all recorded skills and new forms of knowledge would need to be up to date at the time of revolunteering; this would have indicated a requirement for a different approach to constructing, storing, and managing the database for legacy.

A potential success in terms of knowledge addition was found in the sport of luge. Often sporting organizations and lead bodies arrive at the event with their operational knowledge in place and often bringing in a team with them. Upon event completion, they move on to the next event, possibly leaving some additional knowledge, or transfer skills within local sports but with little opportunity or intentionality to transfer more widely. Key luge volunteers explained that there had been a recognized lack of local knowledge as they were building a luge track for the first time in the area. A longterm strategy led to the recruitment and training of volunteers to be officials nearly 3 years prior to the event. New explicit knowledge has been internalized through practice and this knowledge remains, enabling an ability to host future World Cup events (Banks, 2011). What is important in this example is recognition and commitment to the long lead time required to make this possible.
Overall, what became clear from the postVancouver 2010 Games workshop was the lack of expectation by volunteer organizations of what the potential human capital legacy could have been for them and what they needed to do in order to leverage that opportunity. One interviewee, from Whistler Adaptive Sports, was a notable exception in that she had thought about it, planned, and was now harnessing the new people and skills at her disposal; she was very clear that this was only possible because she had actively planned for skills acquisition prior to, and during, the Games.

Table 4 considers the process elements of the $\mathrm{KVC}$. What can be seen is that there is remarkably little movement between the different forms of knowledge, despite these being the processes that should be encouraging movement.

The most notable gap in the KM acquisition process was the lack of a long-term vision or strategy evident in the training. Participants noted that, especially as it got closer and closer to the commencement of the Vancouver 2010 Games, the numbers to be trained and the time demands meant the training focused on the mechanisms of the Vancouver 2010 Games, developing volunteer enthusiasm, providing knowledge of the Vancouver 2010 Games, and the ensuring delivery of the event in terms of tasks and health and safety (VANOC, 2008). Although critical for delivering the Vancouver 2010 Games the context-specific knowledge gained by volunteers was not useful outside the Vancouver 2010 Games and no other knowledge legacy was evident. The importance of managed reflection has been noted in several learning theories (see e.g., Argyris, 1976; Kayes, 2002; Kolb, 1984) and would be vital if the knowledge amassed through an application of the KVC was to then trigger the SECI cycle and lead to novelty and human capital legacy. However, most of the VANOC team's contracts had ended within 1 month of the Vancouver 2010 Games and that time was spent shutting down the event rather than learning from the experience. Collating the range of other examples shown in Tables 5 and 6 into an analysis of the KVC demonstrates that many aspects were not identified at all (Fig. 3).

From this analysis against the SECI and KVC, it is clear that many elements are either limited or 


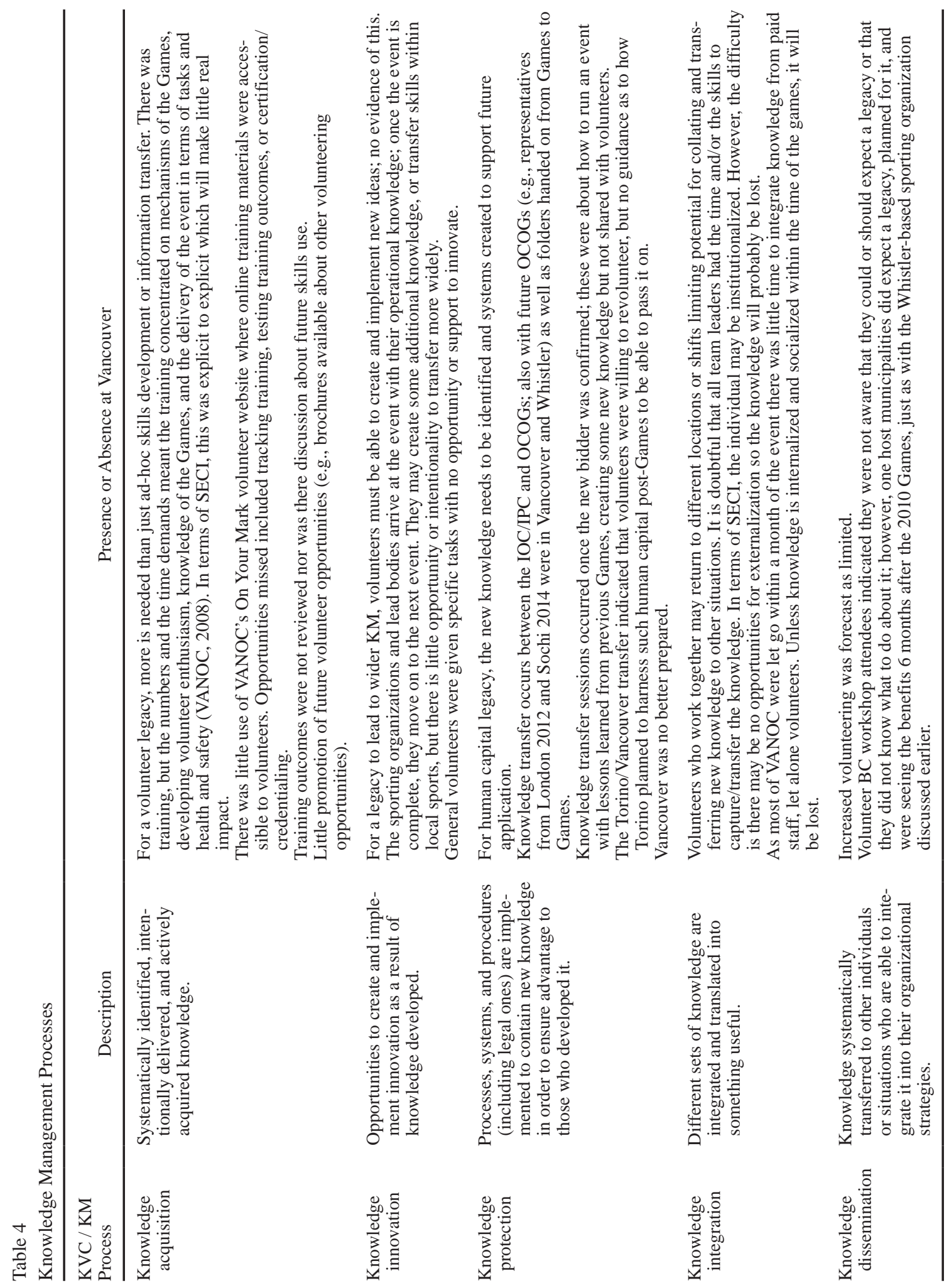




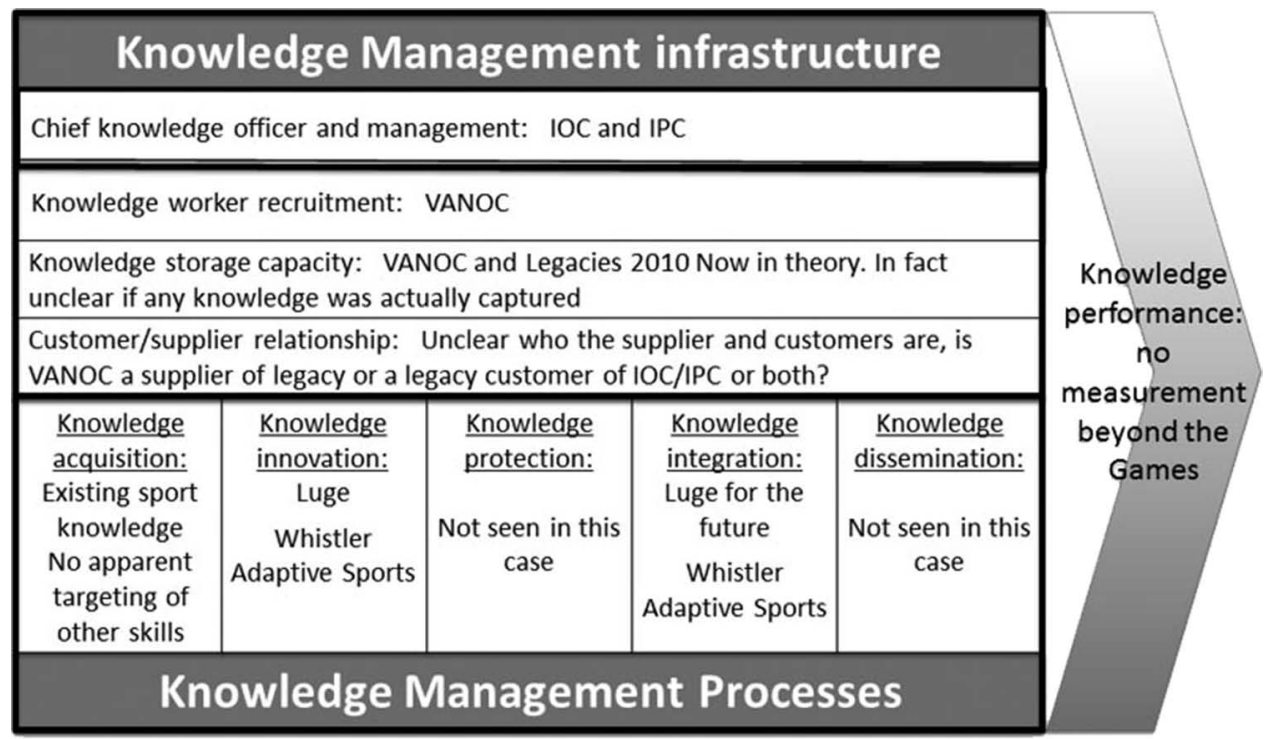

Figure 3. The knowledge value chain in action: Vancouver 2010 Games.

lacking in the case study of the Vancouver 2010 Games. The question that this raises is, would a more proactive KM approach have increased the possibility of a human capital legacy post the Vancouver 2010 Games and, if so, what lessons can be learned from this?

\section{Implications}

If an anticipated and desired outcome of an event is a human capital legacy we argue that a more considered, proactive approach needs to be adopted pre-Games, in both planning and budgeting, to enable the legacy to be achieved and managed postevent. The anticipated human capital legacy of knowledge needs to be clearly articulated to ensure recognition of what it is, what it is for, and why it is needed (Fahey \& Prusak, 1998), and that the necessary inputs and processes may be designed to support its achievement. We argue that the different aspects of the KVC may trigger questions regarding necessary $\mathrm{KM}$ infrastructure elements or organizational processes to facilitate a human capital legacy. From the answers that emerge, it will be clear whether the infrastructure and processes required are in place and, if not, focus their development. Again, consideration needs to be around a formal and structured discussion considering required elements/processes and their establishment.

Figure 4 provides an example of the KVC for mega-sport events focused on achieving a human capital legacy where each element of infrastructure and process has been completed, including the projected outcomes and achievement goals, with the addition of a planning stage, which is on the right hand side of the original model. For example, prior to presenting their bid the volunteer legacy would ideally be embedded into the bid requirements including the post-Games evaluations and the planning and funding for post-Games legacies. The first step a mega-event bid team would undertake would be to identify the aspects of legacy desired and achievable including more volunteers for an area, better skilled volunteers for event management, and specialist volunteers for a particular event. The next stage would be to identify how that would be demonstrated in terms of recognizing the knowledge required and how it can be shown to have been developed and disseminated beyond the event. Following this, both the infrastructure and process requirements for the desired outcome may be identified and entered into the framework. It may be that several chains are developed for different forms or contexts of volunteering, or different forms of knowledge, depending on the type 


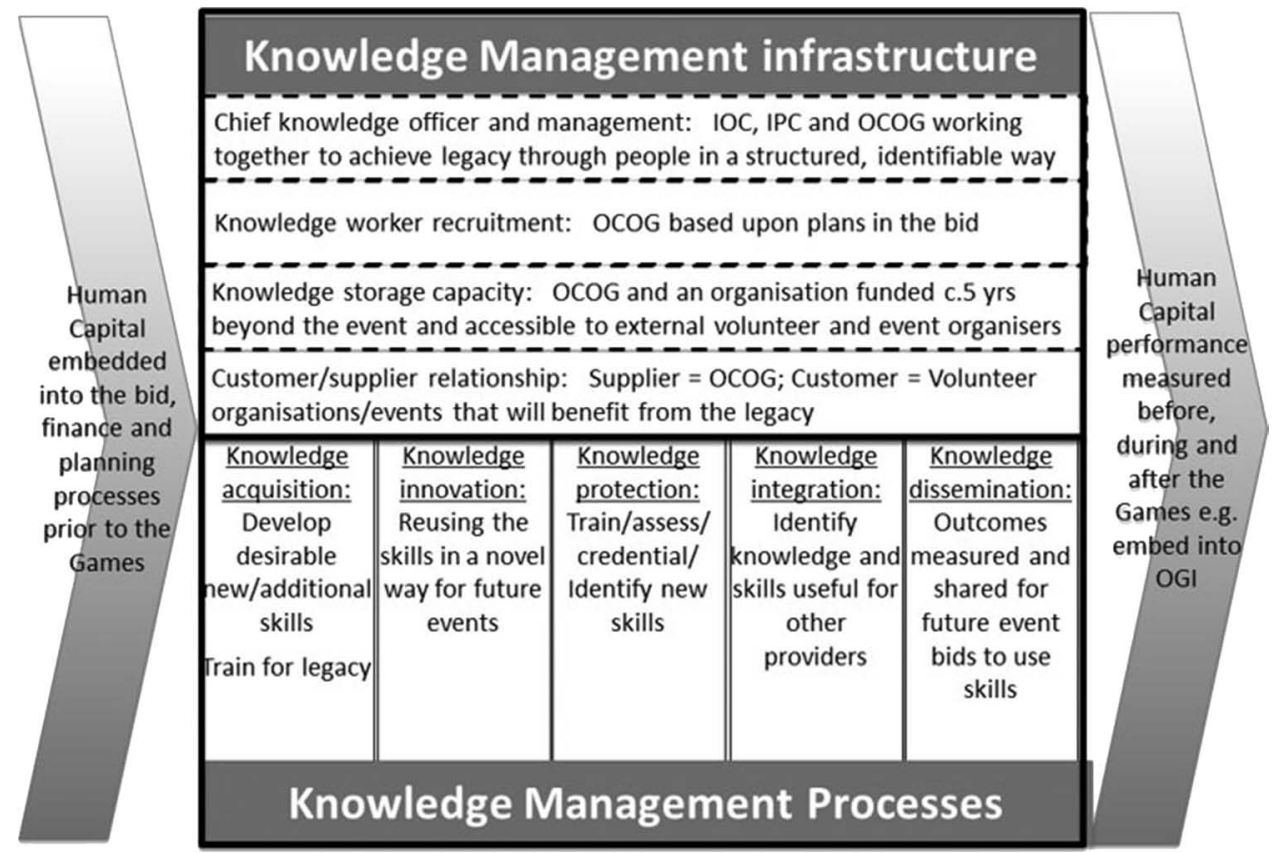

Figure 4. Human capital legacy development for future mega-sport events.

and scale of the event in question. The more detail the structured conversations between stakeholders leads to in terms of the way the framework is completed, the more likelihood that there will be successful human capital and event legacy outcomes.

\section{Conclusion}

The official discourses of the Games engage in a rhetoric of a volunteering legacy. Such conversations are not limited to the Olympics and Paralympics, but is also seen with other international mega-sport events such as the Commonwealth Games, and the Rugby and FIFA World Cups across developed and emerging economies (e.g., Bang, Lee, \& Swart, 2014; Human \& Van Graan, 2013; Nichols \& Ralston, 2012; Smith \& Dickson, 2013; Tewari, 2014). At the same time the academic literature already recognizes that legacy is not something that just happens it needs to be planned and managed (see Dickson, Benson et al., 2011; Dickson et al., 2015; Misener, Darcy, Legg, \& Gilbert, 2013; Preuss, 2007) in order to maximize its impact. However, what is also evident is that there is a "legacy gap" (see Benson et al., 2014) between the discourses surrounding the Vancouver 2010 Games and the reality in terms of delivery of the legacy statements. This article supports the view that mega-events, such as the Vancouver 2010 Games, need to plan for and manage legacy much more carefully if it is to be created, captured, and capitalized on in the future. More specifically, it is suggested that current underpinning assumptions about human capital legacy development in megasport events are misleading, resulting in less legacy outcomes than had been anticipated or promised to the public.

This article proposes that knowledge as a concept can provide a framework that supports the development of human capital legacies to emerge from mega-sport events. Moreover, it is argued that by applying a KM lens to human capital legacy development, alternative perspectives of legacy development may be considered. An application of the KVC theory as a way to manage knowledge through both storing of knowledge and triggering the SECI process is presented. Applying the theory to the Vancouver 2010 Games demonstrates 
that 1) a clear KM approach to legacy was lacking, both in infrastructure and processes, and that 2) using a KM framework could clarify why there was unlikely to be the development of long-term human capital legacy.

Although this article is limited to one case, those aspiring to human capital legacy development from volunteering in a given scenario offer a potential KM framework for use. We anticipate that these findings would equally apply to other large megaevents where human capital legacy is an anticipated outcome, but where there is no overt plan or vision as to how to achieve it in a managed way. Future research should consider the relationship between $\mathrm{KM}$ and human capital legacy development in general and, more specifically, test the proposed framework as a way to capture, store, and reuse legacy knowledge in a range of contexts.

\section{Notes}

${ }^{1}$ Vancouver 2010 Games is used as an abbreviation for Vancouver 2010 Olympic and Paralympic Winter Games.

${ }^{2}$ London 2012 Games is used as an abbreviation for London 2012 Olympic and Paralympic Summer Games.

${ }^{3}$ The Games is used as a plural, generic abbreviation for Olympic and Paralympic Games, which are held every 4 years in a different country, regardless of whether they are summer or winter events.

${ }^{4}$ Every Games has a host country organizing committee referred to as an OCOG. The abbreviation OCOG is often changed to make it country specific (e.g., VANOC for the Vancouver Organizing Committee, LOCOG for the London Organizing Committee of the Olympic Games).

${ }^{5}$ This study was part of a larger scale study on the Vancouver 2010 Games, which included pre- and post-Vancouver 2010 Game Surveys. The questionnaires were hosted on www.surveymethods.com. The presurvey was sent to all 19,104 VANOC volunteers in January 2010. A convenience sample of 2,397 responses were gathered, of which 2,066 were useable (see Dickson et al., 2013). The postsurvey was distributed widely using a snowball sampling technique. The response rate was low with 219 responses (see Benson et al., 2014).

\section{References}

Ambrosini, V., \& Bowman, C. (2001). Tacit knowledge; some suggestions for operationalization. Journal of Management Studies, 38(6), 811-829.

Andranovich, G., Burbank, M. J., \& Heying, C. H. (2001). Olympic cities: Lessons learned from mega-event politics. Journal of Urban Affairs, 23(2), 113-131.
Argyris, C. (1976). Single-loop and double-loop models in research on decision-making. Administrative Science Quarterly, 21(3), 363-375.

Azzoni, T. (2009). Rio carrying Olympic hopes of entire continent. ESPN. Retrieved from http://sports.espn.go.com/ espn/wire?id=4498078

Bang, H., Lee, S., \& Swart, K. (2014). Predicting volunteers’ intention to return: An examination of brand personality, prestige, and identification of sporting events. Event Management, 18(2), 169-183.

Banks, F. (2011). Insider's guide to Whistler's Olympic legacies. The Whistler Insider. Retrieved from http://www. whistler.com/blog/post/2011/12/08/Whistler-OlympicLegacies.aspx

Benson, A. M., Dickson, T. J., Terwiel, A., \& Blackman, D. (2014). Training of Vancouver 2010 volunteers: A legacy opportunity? Contemporary Social Science: Journal of the Academy of Social Sciences, 9(2), 210-226.

Bowen, G. (2009). Document analysis as a qualitative research method. Qualitative Research Journal, 9(2), 27-40.

Cai, G. N. (2014). Research on impact of medical people based on cloud SECI accounting theory. Advanced Materials Research, 971, 2368-2371.

Cashman, R. (2006). The bitter-sweet awakening: The legacy of the Sydney 2000 Olympic Games. Sydney, Australia: Walla Walla Press.

Chalip, L. (2006). Towards social leverage of sport events. Journal of Sport Tourism, 11(2), 109-127.

Chalkiti, K., \& Sigala, M. (2008). Information sharing and knowledge creation in online forums: The case of the Greek Online Forum "DIALOGOI." Current Issues in Tourism, 11(5), 381-406.

Chua, A. (2002). The influence of social interaction on knowledge creation. Journal of Intellectual Capital, 3(4), 375-392.

Coleman, J. (1988). Social capital in the creation of human capital. American Journal of Sociology, 94, S94-S120.

Cook, S. D. N., \& Brown, J. S. (1999). Bridging epistemologies: The generative dance between organizational knowledge and organizational knowing. Organization Science, 10(4), 381-400.

Cooper, C. (2006). Knowledge management and tourism. Annals of Tourism Research, 33(1), 47-64.

Crook, T. R., Todd, S. Y., Combs, J. G., Woehr, D. J., \& Ketchen Jr., D. J. (2011). Does human capital matter? A meta-analysis of the relationship between human capital and firm performance. Journal of Applied Psychology, 96(3), 443-456.

Dalkir, K. (2011). Knowledge management in theory and practice (2nd ed.). Cambridge, MA: Massachusetts Institute of Technology.

Davenport, T. H., \& Prusak, L. (2000). Working knowledge: How organizations manage what they know. Boston, MA: Harvard Business School Press.

de Moragas, M., Moreno, A. B., \& Puig, N. (2000). Conclusions and recommendations: International symposium on volunteers, global society and the Olympic movement. 
In M. de Moragas, A. B. Moreno, \& N. Puig (Eds.), Volunteers, global society and the Olympic movement: International Symposium 24-26 November, 1999 (pp. 355-358). Lausanne, Switzerland: IOC.

Department for Culture Media and Sport. (2010). Plans for the legacy from the 2012 Olympic and Paralympic Games. Retrieved from https://www.gov.uk/government/ uploads/system/uploads/attachment_data/file/78105/20 1210_Legacy_Publication.pdf

Dickson, T. J., Benson, A. M., \& Blackman, D. A. (2011). Developing a framework for evaluating Olympic and Paralympic legacies. Journal of Sport and Tourism, 16 (4), 285-302.

Dickson, T. J., Benson, A. M., Blackman, D. A., \& Terwiel, F. A. (2013). It's all about the Games! 2010 Vancouver Olympic and Paralympic Winter Games Volunteers. Event Management, 17(1), 77-92.

Dickson, T. J., Darcy, S., Edwards, D., \& Terwiel, F. A. (2015). Sport mega-event volunteers' motivations and post-event volunteering behaviour: The Sydney World Masters Games, 2009. Event Management, 19(2), 227-245.

Dickson, T. J., Terwiel, F. A., \& Benson, A. M. (2011). Volunteers of the 2010 Olympic and Paralympics Winter Games: Lessons for the future. In G. Romanova (Ed.), IV International Conference: Education and training for the XXII Sochi 2014 Winter Olympic and Paralympic Games: Challenges and solutions (pp. 19-32), October 24-25, 2011, Sochi State University, Sochi.

Doherty, A. J. (2009). The volunteer legacy of a major sport event. Journal of Policy Research in Tourism, Leisure and Events, 1(3), 185-207.

Easa, N., \& Fincham, R. (2012). The application of the socialisation, externalisation, combination and internalisation model in cross-cultural contexts: Theoretical analysis. Knowledge \& Process Management, 19(2), 103-109.

Eisenhardt, K. M., \& Santos, F. M. (2002) Knowledge-based view: A new theory of strategy? In A. M. Pettigrew, H. Thomas, \& R. Whittington (Eds.), Handbook of strategy and management, (pp. 139-164). London: Sage Publications.

Fahey, L., \& Prusak, L. (1998). The eleven deadliest sins of knowledge management. California Business Review, 40(3), 265-276.

Forbes, K. F., \& Zampelli, E. M. (2014). Volunteerism: The influences of social, religious and human capital. Nonprofit \& Voluntary Sector Quarterly, 43(2), 227-253.

Ghaffar, A. R. A., Beydoun, G., Shen, J., \& Tibben, W. (2011). Towards knowledge management in sports event management: Context analysis of Malaysian biannual games with CommonKADS. ICSOFT 2011: 6th International Conference on Software and Data Technologies (pp. 377-383). Spain: SciTePress.

Gherardi, S. (2006). Organizational knowledge: The texture of workplace learning. Oxford, UK: Blackwell Publishing Ltd.

Gold, J. R., \& Gold, M. M. (2008). Olympic cities: Regeneration, city rebranding and changing urban agendas. Geography Compass, 2(1), 300-318.
Gourlay, S. (2006). Conceptualizing knowledge creation: A critique of Nonaka's theory. Journal of Management Studies, 43(7), 1415-1436.

Grant, R. M. (1996). Toward a knowledge-based theory of the firm. Strategic Management Journal, 17, 109-122.

Gratton, L., \& Ghoshal, L. (2003). Managing personal human capital: New ethos for the "volunteer" employee. European Management Journal, 21(1), 1-10.

Halbwirth, S., \& Toohey, K. (2001). The Olympic Games and knowledge management: A case study of the Sydney organising committee of the Olympic Games. European Sport Management Quarterly, 1(2), 91-111.

Hallmann, K., \& Harms, G. (2012). Determinants of volunteer motivation and their impact on future voluntary engagement: A comparison of volunteer's motivation at sport events in equestrian and handball. International Journal of Event and Festival Management, 3(3), 272-291.

Harmaakorpi, V., \& Melkas, H. (2005). Knowledge management in regional innovation networks: The case of Lahti, Finland. European Planning Studies, 13(5), 641-659.

Heisig, P. (2009). Harmonisation of knowledge management-comparing $160 \mathrm{KM}$ frameworks around the globe. Journal of Knowledge Management, 13(4), 4-31.

Hiller, H. H. (2000). Mega-events, urban boosterism and growth strategies: An analysis of the objectives and legitimations of the Cape Town 2004 Olympic bid. International Journal of Urban and Regional Research, 24(2), 439-458.

Hislop, D. (2013). Knowledge management in organizations: A critical introduction (3rd ed.). Oxford, UK: Oxford University Press.

Hodgkin, R. A. (1992). Michael Polyani on the activity of knowing - the bearing of his own ideas on the theory of multiple intelligences. Oxford Review of Education, 18(3), 252-267.

Hong, J. F. L. (2012). Glocalizing Nonaka's knowledge creation model: Issues and challenges. Management Learning, 43(2), 199-215.

Hsu, I., \& Sabherwal, R. (2012). Relationship between intellectual capital and knowledge management: An empirical investigation. Decision Sciences, 43(3), 489-524.

Human, L. H., \& Van Graan, M. (2013). South African volunteers' experiences of volunteering at the 2010 FIFA World Cup South Africa: Sport. African Journal for Physical Health Education, Recreation and Dance, 19 (2), 345-359.

International Olympic Committee. (2006). Torino 2006 Olympic Experience-Official debriefing: Handout. July 10-14, Vancouver.

Kasimati, E. (2003). Economic aspects and the Summer Olympics: A review of related research. International Journal of Tourism Research, 5(6), 433-444.

Kayes, D. C. (2002). Experiential learning and its critics: Preserving the role of experience in management learning and education. Academy of Management Learning \& Education, 1(2), 137-149. 
Kissoudi, P. (2008). The Athens Olympics: Optimistic legacies-Post-Olympic assets and the struggle for their realization. International Journal of the History of Sport, 25(14), 1972-1990.

Kolb, D. A. (1984). Experiential learning: Experience as the source of learning and development. Englewood Cliffs, NJ: Prentice-Hall Inc.

Lee, C. S., \& Kelkar, R. S. (2013). ICT and knowledge management: Perspectives from the SECI model. The Electronic Library, 31(2), 226-243.

Lee, C. C., \& Yang, J. (2000). Knowledge value chain. Journal of Management Development, 19(9), 783-793.

Lettieri, E., Borga, F., \& Savoldelli, A. (2004). Knowledge management in non-profit organizations. Journal of Knowledge Management, 8(6), 16-30.

Lin, C., \& Tseng, S. M. (2005). The implementation gaps for the knowledge management system. Industrial Management \& Data Systems, 105(2), 208-222.

Liu, G., \& Ko, W. W. (2012). Organizational learning and marketing capability development: A study of the charity retailing operations of British social enterprise. Nonprofit and Voluntary Sector Quarterly, 41(4), 580-608.

Love, A., Hardin, R. L., Koo, G.-Y., \& Morse, A. (2011). Effects of motives on satisfaction and behavioral intentions of volunteers at a PGA tour event. International Journal of Sport Management, 12(1), 86-101.

Misener, L., Darcy, S., Legg, D., \& Gilbert, K. (2013). Beyond Olympic legacy: Understanding Paralympic legacy through a thematic synthesis. Journal of Sport Management, 27(4), 329-341.

Newell, S., Robertson, M., Scarborough, H., \& Swan, J. (2009). Managing knowledge work and innovation (2nd ed.). Hampshire, UK: Palgrave Macmillan.

Nichols, G., \& Ralston, R. (2012). Lessons from the volunteering legacy of the 2002 Commonwealth Games. Urban Studies, 49(1), 169-184.

Nickerson, J. A., \& Zenger, T. R. (2004). A knowledgebased theory of the firm: The problem solving perspective. Organization Science, 15(6), 617-632.

Nonaka, I. (1994). A dynamic theory of organizational knowledge creation. Organization Science, 5(1), 14-37.

Nonaka, I., \& Takeuchi, H. (1995). The knowledge creating company. How Japanese companies create the dynamics of innovation. New York: Oxford University Press.

Nonaka, I., \& Toyama R. (2003). The knowledge-creating theory revisited: Knowledge creation as a synthesizing process. Knowledge Management Research and Practice, 1(1), 2-10.

Noy, C. (2008). Sampling knowledge: The hermeneutics of snowball sampling in qualitative research. International Journal of Social Research Methodology, 11(4), 327-344.

Olympics cost B.C. $\$ 925$ M. B.C. says $74 \%$ went toward sports venues, transportation, other investments. (2010). CBC News. Retrieved from http://www.cbc.ca/news/can ada/british-columbia/olympics-cost-b-c-925m-1.934931

Parent, M. M., MacDonald, D., \& Goulet, G. (2014). The theory and practice of knowledge management and transfer: The case of the Olympic Games. Sport Management Review, 17(2), 205-218.

Patton, M. (1999). Enhancing the quality and credibility of qualitative analysis. Health Services Research, 34(5 Pt. 2), 1189-1208.

Peachey, J. W., Lyras, A., Cohen, A., Bruening, J. E., \& Cunningham, G. B. (2013). Exploring the motives and retention factors of sport-for-development volunteers. Nonprofit and Voluntary Sector Quarterly, 43(6), 1052-1069.

Porter, M. E. (1985). Competitive advantage. New York: Free Press.

Powell, T. (2001). The knowledge value chain (KVC): How to fix it when it breaks. In M. E. Williams (Ed.), Proceedings of the 22nd national online meeting. Medford, $\mathrm{NJ}$ : Information Today Inc. Retrieved from www.tarrani.net/ kate/docs/KnowledgeValueChain.pdf

Preuss, H. (2007). The conceptualisation and measurement of mega sport event legacies. Journal of Sport Tourism, 12(3/4), 207-228.

Rae, J. (2008). Whistler-Leveraging the Olympics presentation and tour. Paper presented at the AIEST 2008: Real Estate market: Impacts on Tourism Destinations, Whistler, BC.

Resort Municipality of Whistler. (2010). Living the dream: 2010 Winter Games post-Games report. Retrieved from https://www.whistler.ca/sites/default/files/related/living 20the20dream20-20final20report2028329.pdf

Sandelowski, M. (1995). Sample size in qualitative research. Research in Nursing \& Health, 18(2), 179-183.

Sarirete, A., \& Chikh, A. (2010). A knowledge management process in communities of practice of engineering based on the SECI model for knowledge. Web-Based Learning and Teaching Technologies, 5(1), 27-42.

Seleim, A. A. S., \& Khalil, O. E. M. (2011). Understanding the knowledge management-intellectual capital relationship: A two-way analysis. Journal of Intellectual Capital, 12(4), 586-614.

Shaw, G., \& Williams, A. (2009). Knowledge transfer and management in tourism organisations: An emerging research agenda. Tourism Management, 30(3), 325-335.

Smith, K., \& Dickson, G. (2013). Experiences and legacies of Rugby World Cup 2011 volunteer programme-summary report. Wellington, New Zealand: Victoria University of Wellington.

Sochi 2014. (2009). Motivation, Sochi 2014 candidature file, our bid Sochi 2014. Retrieved from http://sochi2014. com/36108

Sochi 2014. (2014, 20 February). IOC observer programme provides "behind the scenes" experience for future Games organisers. Retrieved from http://www.olym pic.org/news/ioc-observer-programme-provides-beh ind-the-scenes-experience-for-future-games-organi sers $/ 225497$

Stadler, R., Fullagar, S., \& Reid, S. (2014). The professionalization of festival organizations: A relational approach to knowledge management. Event Management, 18(1), 39-52. 
Swan, J., Newell, S., Scarborough, H., \& Hislop, D. (1999). Knowledge management and innovation: Networks and networking. Journal of Knowledge Management, 3(4), 262-275.

Taylor, A. (2013). Russia is spending a ludicrous amount of money on the Winter Olympics. Business Insider Australia. Retrieved from http://www.businessinsider.com/ sochi-olympics-cost-russia-51-billion-2013-2?utm_ source $=$ dlvr.it\&utm_medium $=$ twitter

Tewari, S. (2014). The Commonwealth Games Delhi 2010: Volunteers in sport and leisure. In F. M. L. Verde, I. Modi, \& G. Cappello (Eds.), Mapping leisure across borders (pp. 229-238). Cambridge, UK: Cambridge Scholars Publishing.

Tsoukas, H., \& Vladirimou, E. (2001). What is organizational knowledge? Journal of Management Studies, 38(7), 973-993.

VANOC. (2008). My Games training, Vancouver 2010 Olympic and Paralympic Winter Games, participant's guide. Vancouver: Author.

VANOC. (2010). Staging the Olympic Winter Games knowledge report. Vancouver: Author.
Williams, P. W., \& Elkhashab, A. (2012). Leveraging tourism social capital: The case of the 2010 Olympic tourism consortium. International Journal of Event and Festival Management, 3(3), 317-334.

Wilson, J. (2000). Volunteering. Annual Review of Sociology, 26(1), 215-240.

Wilson, J., \& Musick, M. (1998). The contribution of social resources to volunteering. Social Science Quarterly, 79(4), 799-814.

Wong, H. K. (2004). Knowledge value chain: Implementation of new product development system in a winery. The Electronic Journal of Knowledge Management, 2(1), 77-90.

Wong, K. Y., \& Aspinwall, E. (2004). Knowledge management implementation frameworks: A review. Knowledge and Process Management, 11(2), 93-104.

Yang, J. T., \& Wan, C. S. (2004). Advancing organizational effectiveness and knowledge management implementation. Tourism Management, 25(5), 593-601.

Yin, R. K. (2014). Case study research: Design and methods (5th ed.). Thousand Oaks, CA: Sage Publications Inc. 